ANUVA Volume 2 (3): 253-272, 2018

Copyright @2018, ISSN: 2598-3040 online

Available Online at: http://ejournal.undip.ac.id/index.php/anuva

\title{
PERS, PERATURAN NEGARA, DAN NASIONALISME INDONESIA
}

\author{
Dewi Yuliati ${ }^{1 *}$ \\ ${ }^{1}$ Program Studi Sejarah, Fakultas Ilmu Budaya, Universitas Diponegoro, Jl. Prof. Soedarto, SH, Kampus Undip \\ Tembalang, Semarang, Indonesia \\ ${ }^{*}$ Korespondesi: dewi_yulliati@yahoo.co.id
}

\begin{abstract}
[Press, Government Regulation, and Indonesian Nationalism]. This article presents study about the relationship between the Indonesian press and press regulations since the Dutch colonial era untilThe Indonesian Revolution periods. In these periods, Dutch colonial, the Japanese, and the Indonesian government still put into effect many suppressive laws. This study shows that although the Indonesian press lived in suppressive atmosphere, the Indonesian press dared to perform social responsibility function to get better life and freedom of the Indonesian nation and land.
\end{abstract}

\section{Keywords: Indonesian Press; Press Regulations; Nationalism}

\begin{abstract}
Abstrak
Artikel ini berisi pembahasan tentang hubungan antara Pers Indonesia dan peraturan-peraturan tentang pers sejak masa Kolonial Belanda sampai dengan Masa Revolusi Indonesia. Dalam rentang masa tersebut, pemerintah kolonial Belanda, Pemerintah Militer Jepang, dan Pemerintah Indonesia tetap memberlakukan undang-undang yang bersifat suppressive. Hasil penelitian ini menunjukkan bahwa meskipun hidup dalam suasana suppressive, Pers Indonesia selalu berani untuk melaksanakan fungsi tanggungjawab sosial demi mencapai kehidupan yang lebih baik dan kebebasan bagi bangsa dan Negara Indonesia.
\end{abstract}

Kata Kunci: Pers Indonesia; Peraturan tentang Pers; Nasionalisme

\section{Pendahuluan}

Kata pers atau press memiliki makna yang mencakup: alat atau mesin pencetak, percetakan dan penerbitan, media cetak seperti koran, majalah, buletin, dan sebagainya. Dewasa ini, pers diartikan secara lebih luas, yaitu usaha-usaha pengelola media komunikasi massa untuk memenuhi kebutuhan masyarakat akan informasi, hiburan, berita-berita tentang peristiwa-peristiwa yang telah atau akan terjadi di sekitar mereka. Media komunikasi massa dapat berwujud surat kabar, majalah, buletin, kantor-kantor berita, radio, televisi, dan film.

Fokus pembahasan dalam artikel ini adalah pers dalam pengertian media cetak, khususnya surat kabar atau koran. Peneliti melihat bahwa ada hubungan antara kelahiran serta perkembangan pers nasional Indonesia dan sistem kolonialisme Belanda yang semakin intensif pada awal abad ke-20. Berdasarkan hubungan itu, kajian ini mengemukakan dua pertanyaan utama yaitu: pertama, bagaimana negara mengatur kehidupan pers sejak masa kolonial Belanda sampai dengan masa revolusi Indonesia; ke dua, bagaimana 
pers Indonesia melakasanakan fungsi social responsibility bagi rakyat Indonesia di bawah sistem pengaturan pers oleh negara itu.

\section{Landasan Teori}

Untuk menjelaskan hubungan antara pers dan negara, serta fungsi pers sebagai media ekspresi nasionalisme Indonesia, lebih dulu dikemukakan beberapa teori tentang fungsi pers (Rachmadi, 1996: 31-47). Teori yang tertua adalah teori pers otoritarian (authoritarian theory). Menurut teori yang mulai berkembang di Eropa pada Abad Pertengahan ini, pers dapat dimiliki oleh swasta, tetapi harus diselenggarakan untuk memenuhi kepentingan penguasa atau pemerintah. Dalam sistem pemerintahan otoriter, fungsi pers diatur agar dapat membatasi ekspresi kebebasan berpendapat yang dapat mengancam stabilitas kekuasaan. Pers harus dapat melayani kepentingan penguasa.

Sejalan dengan perkembangan liberalisme di Barat pada abad ke-18, pers mengalami perubahan fungsi. Dalam masyarakat penganut paham liberal, yang mengutamakan kebebasan berpendapat, berkembang libertarian theory (teori libertarian). Berdasarkan teori libertarian, pers dituntut untuk dapat berfungsi sebagai media yang mengekspresikan kebenaran. Menurut paham liberal, setiap orang memiliki hak yang sama untuk berpendapat melalui pers, hak alamiah yang bukan berasal dari penguasa.

Karena kemuliaan fungsi pers itu, Mark Twain mengatakan bahwa "hanya ada dua hal yang dapat membuat segala sesuatu terang di bumi ini, yaitu matahari di langit dan pers di dunia". Senada dengan ungkapan Mark Twain itu, Wilbur Schramm menyatakan bahwa pers berfungsi terutama memberi informasi yang obyektif kepada pembaca tentang apa yang terjadi dalam lingkungannya, negaranya, dan yang terjadi di dunia (Schramm, 1977: 38; Rachmadi, 1990: 19).

Sejalan dengan terbentuknya negara komunis Uni Soviet, berkembang juga Soviet Communist theory (teori Komunis Soviet) yang menegaskan bahwa pers adalah organ pemerintah. Menurut teori ini, fungsi utama pers adalah sebagai alat negara dan partai komunis untuk menggalang kesatuan, menyebarluaskan komunisme, dan mendukung program-program pemerintah untuk meningkatkan produksi.

Setelah Perang Dunia II, dilakukan modifikasi terhadap teori libertarian, terutama oleh Peterson yang mengemukakan social responsibility theory (teori tanggung jawab sosial). Menurut teori ini, pers memiliki fungsi sebagai berikut: (1). menyediakan informasi, diskusi dan debat tentang sistem politik yang sedang berlangsung, (2). memberi penerangan kepada publik dan mendorong pembentukan self-government (pemerintahan sendiri), (3). menjadi pengawas atau kontrol terhadap pemerintah, dan melindungi hak-hak individu, (4). mempertemukan pembeli dan penjual barang-barang melalui advertensi, (5). menyediakan hiburan.

Pemahaman tentang teori-teori tentang fungsi pers akan memperjelas pemahaman mengapa negara selalu berkepentingan untuk membuat ketentuan-ketentuan yang mengatur pers. Di bawah ini disajikan pembahasan tentang peraturan-peraturan negara tentang pers dari masa kolonial Belanda sampai masa setelah kemerdekaan Indonesia. 


\section{A. Peraturan Negara Tentang Pers}

\section{a. Peraturan-peraturan Pemerintah Kolonial Belanda}

Untuk memahami hubungan antara pers bumiputera, negara kolonial dan nasionalisme Indonesia sangatlah menarik untuk disimak pernyataan Sidik Djojosoekarto sebagai berikut.

Bahwa pada hakekatnya pers dan pergerakan rakyat itu adalah satu badan belaka. Maka dari itu kita percaya bahwa keduanya bersama-sama menanggung beban yang berat sekali. Rakyat yang sadar dan insyaf akan kewajibannya mesti mengakui betapa besar guna dan faedah pers kebangsaan bagi kemajuan dan bagi pergerakannya. Maka dari itu kemerdekaan pers kebangsaan kita bukan kebutuhan kaum jurnalis kita saja, akan tetapi juga dan memang menjadi kebutuhan rakyat kita. Jadi, bilamana kaum pergerakan kita, rakyat pada umumnya membantu akan didapatkannya kemerdekaan pers kebangsaan dan mempertahankan kemerdekaan itu, sebetulnya itu hanyalah bekerja untuk kepentingan kita sendiri. Maka teranglah sekarang bagi kita, bahwa pergerakan rakyat dan pers kebangsaan itu bagi pemerintah kolonial tak berbeda (Pitut Soeharto dan zainoel Ihsan, 1982: 273274)

Dari pernyataan yang telah dipaparkan di atas dapat diketahui bahwa pada era kolonial Belanda, pers bumiputera adalah bagian yang tidak terpisahkan dari pergerakan nasional Indonesia. Sartono Kartodirdjo menyatakan pers bumiputera dan pergerakan nasional adalah kembar siam, dua bidang kegiatan bangsa Indonesia yang hidup berdampingan secara simbiotik; ada saling ketergantungan secara organik, yang satu sulit mempertahankan eksistensinya tanpa yang lain (Kartodirdjo, 1990: 116). Katodirdjo memaparkan fungsi dan potensi pers bumiputera pada era kolonial Belanda sebagai berikut.

1) membuat revolusi komunikasi dari komunikasi lisan ke komunikasi tertulis sehingga tidak berubahubah dalam proses penerusannya.

2) menciptakan komunikasi terbuka, informasi dapat diperoleh oleh golongan sosial mana pun.

3) membangkitkan kesadaran kolektif rakyat tentang keamanan, kesejahteraan, kemasyarakatan, ketatanegaraan, dan sebagainya.

4) menambah kesadaran politik pembaca.

5) mengintegrasikan kaum terpelajar baik secara regional maupun nasional, sekaligus juga menciptakan segmentasi menurut aliran politik, kepentingan golongan dan kelompok sosial lainnya (Kartodirdjo, 1990: 115-116)

Pers, karena sifatnya yang tertulis sehingga dapat dibaca berulang-ulang, adalah media yang efektif untuk mempengaruhi dan membangun opini publik. Oleh sebab itu, sejak pertengahan abad ke-19 pemerintah kolonial Belanda sudah menyediakan perangkat hukum untuk mengendalikan pers.

Peraturan pertama tentang pers ditetapkan pada tahun 1856, yang dinamakan Reglement $O p$ De Drukwerken in Nederlandsch-Indië (peraturan tentang pers di Hindia Belanda) (Staatsblad 1856 No. 74). 
Peraturan ini merupakan reaksi terhadap perkembangan pers swasta di daerah koloni yang berkarakter liberal. Dalam pandangan pemerintah kolonial, pers liberal sering mengganggu ketertiban umum karena sifatnya yang blak-blakan (terus terang) dan menghasut. Reglement $O p$ de Drukwerken tahun 1856 dapat dikatakan sebagai alat untuk mengekang kebebasan pers dan cara untuk menindak siapa saja yang melontarkan kritik terhadap pemerintah kolonial. Pasal 13 peraturan ini mencerminkan sistem pengawasan preventif sebagai berikut:

Satu eksemplar segala karya cetak, sebelum diterbitkan, harus dikirimkan dulu kepada kepala pemerintahan setempat, pejabat justisi, dan Algemeene Secretarie (Kesekretariatan Negara). Pengiriman harus dilakukan oleh pihak pencetak atau penerbit dengan tanda tangan. Pelanggar pasal ini dikenai denda sebesar f. 50,-- sampai f. 1.000,-.

Pihak-pihak progresif dalam masyarakat Belanda, baik di negeri Belanda maupun di Hindia Belanda (Indonesia), mencela peraturan itu sebagai reaksi yang paling keras, karena pengawasan preventif (sistem sensor) dipandang sebagai kutukan terhadap kebebasan pers dan juga pelanggaran terhadap Konstitusi Belanda yang melarang sensor terhadap pers (tertulis dalam pasal 7 Konstitusi Belanda). Torbecke, pemimpin liberal Belanda yang terkemuka, menyebut peraturan itu sebagai gewrocht der duisternis (ciptaan kegelapan) (Oemar Senoadji, 1955).

Karena desakan pihak-pihak liberal, Reglement op De Drukwerken 1856 diperbaiki pada tahun 1906. Dengan Koninklijk Besluit (Keputusan Raja), 19 Maret 1906, sistem pengawasan preventif diganti dengan sistem pengawasan represif, yang tercermin terutama pada pasal 13 peraturan tersebut yang mengatur: pencetak dan penerbit berkewajiban menyerahkan satu eksemplar kepada pemerintah daerah setempat dalam waktu 24 jam setelah barang cetak itu beredar. Denda yang dikenakan sebesar f. 10 ,- - f. 100,- (Staatsblad van Nederlandsch-Indië 1906 No. 270)

Akan tetapi, dalam kenyataan, peraturan baru tersebut tidak cukup untuk mengawasi perkembangan kesadaran politik masyarakat di Hindia Belanda. Pada tanggal 2 Juni 1913 Menteri Daerah Jajahan, De Waal Malefijt, mengirim surat kepada Gubernur Jenderal Idenburg tentang gagasannya untuk membatasi kebebasan pers sebagai berikut.

Tindakan yang keras harus dilakukan terhadap khotbah umum yang menentang kekuasaan Belanda, terhadap usaha-usaha yang menjengkelkan untuk mendiskreditkan maksud-maksud baik pemerintah, terhadap tindakan menanam rasa kebencian dan permusuhan di antara kelompok penduduk yang sekarang ini sudah menggejala. Membiarkan tekanan dari fakta-fakta itu dalam perdebatan di antara penguasa-penguasa hukum di Hindia, adalah pembunuhan politik. Selanjutnya saya berpendapat bahwa peraturan seperti itu harus diberlakukan tanpa perbedaan, walaupun pers non-Eropa yang paling berbahaya bagi keamanan dan ketenteraman memerlukan pengawasan yang lebih ketat daripada pers Eropa yang jangkauannya tidak luas, dan memerlukan bantuan pers Bumiputera dan Cina untuk sampai pada berbagai lapisan penduduk. Tentu saja pemberlakuan pengawasan preventif tidak mungkin dengan mengubah drukpersreglement tahun 1906. Oleh karena itu, harus dicari bentuk baru oleh pemerintah, bukan oleh penguasa hukum (Wal, 1967: 239). 
Proses pencarian bentuk represi baru tidak berlangsung lama. Pada tanggal 15 Maret 1914, Strafwetboek (Kitab Undang-undang Hukum Pidana) telah dilengkapi dengan pasal-pasal yang berlaku bagi bangsa Eropa dan bumiputera sebagai berikut.

Pasal 66a:

Barang siapa, baik melalui tulisan, gambar, maupun tindakan, menyebarkan rasa permusuhan, kebencian atau penghinaan kepada pemerintah Belanda atau Hindia belanda, akan dihukum kerja paksa di lingkungannya selama 5 - 10 tahun.

Pasal 66b:

Barang siapa, baik melalui tulisan, gambar, maupun tindakan, menyebarkan rasa permusuhan, kebencian atau penghinaan di antara penduduk Belanda atau Hindia Belanda akan dihukum kerja paksa di luar lingkungannya paling lama 5 tahun. Usaha untuk melakukan kejahatan ini dapat dihukum (Staatsblad 1914 No. 205; Peraturan ini diperbarui dalam Staatsblad 1917 No. 497 dan Staatsblad 1918 No. 289).

Pasal-pasal yang kemudian dikenal dengan Haatzaai Artikelen (pasal-pasal tentang penanaman benih kebencian) ini, setelah tahun 1914, memberi kekuasaan kepada pemerintah untuk mengambil tindakan terhadap pers, jika dikehendaki.

Dalam Strafwetboek tahun 1918, Haatzaai Artikelen tetap diberlakukan, dan diatur dalam pasal 154, 155, 156, dan 157. Pasal 154 dan 155 dikenakan terhadap siapa pun yang menyebarkan perasaan permusuhan, kebencian dan penghinaan terhadap pemerintah Belanda atau Hindia Belanda. Pasal 156 dan 157 dikenakan terhadap pelaku perbuatan seperti tersebut di atas terhadap sekelompok penduduk di Hindia Belanda. Pada dasarnya, materi yang diatur dalam pasal 154 dan 155 adalah sama. Hanya, pasal 155 menyebutkan secara khusus, jika penyebaran rasa kebencian dilakukan melalui tulisan atau gambar. Demikian juga, materi yang diatur dalam pasal 156 dan 157.

Perincian hukumannya adalah sebagai berikut. Untuk pelanggaran terhadap pasal 154, dikenakan hukuman penjara paling lama 7 tahun atau denda paling banyak f. 300,-. Untuk pasal 155, dikenakan hukuman penjara paling lama 4 tahun 6 bulan atau denda paling banyak f. 300,-. Untuk pelanggaran terhadap pasal 156, hukuman penjara yang dikenakan paling lama 4 tahun atau denda sebesar f. 300,-. Untuk pasal 157, dikenakan hukuman penjara paling lamaa 2 tahun 6 bulan atau denda paling banyak f. 300,-( Soerjomihardjo (ed.), 1980:147-148; Periksa juga Sinar Hindia, 26 Agustus 1918).

Meskipun pasal-pasal ini benar-benar diterapkan, kaum jurnalis bumiputera dan tokoh-tokoh pergerakan nasional tidak pernah merasa gentar untuk menyampaikan kritik, pikiran-pikiran, dan ulasanulasan tentang segala hal yang mereka pandang sebagai penyebab kemunduran atau penghambat kemajuan rakyat bumiputera. Bahkan, pada dekade ke-3 abad ke-20, pers bumiputera semakin berani, sehingga mulai tanggal 1 Mei 1926 pemerintah kolonial memberlakukan pasal-pasal lagi yang semakin mempersempit kebebasan pers sebagai berikut.

Pasal 153 bis Strafwetboek (KUHP): 
Barang siapa mengeluarkan kata-kata, tulisan atau gambar secara terang-terangan atau terselubung, yang merusak ketertiban umum atau merusak kekuasaan pemerintah di Belanda dan di Hindia Belanda, dihukum dengan hukuman penjara paling lama 6 tahun atau didenda paling banyak f. 300,-.

Pasal 153 ter Strafwetboek (KUHP):

Barang siapa mengeluarkan tulisan atau gambar secara terang-terangan atau terselubung, yang merusak ketertiban umum atau merusak kekuasaan pemerintah di Belanda atau di Hindia Belanda, dengan tujuan mengumumkan isinya atau memperbanyak, menyebarluaskan, dan memperdengarkannya secara terbuka, dihukum dengan hukuman penjara paling lama 5 tahun atau didenda paling banyak f. 300,-( Kwantes:186).

Pasal-pasal tersebut di atas dianggap masih belum cukup untuk membatasi kebebasan pers, khususnya pers bumiputera. Pada tanggal 7 September 1931 Gubernur Jenderal De Graeff mengumumkan pemberlakuan Persbreidel Ordonnantie (Peraturan tentang Pemberangusan Pers) (Staatsblad van Nederlandsch-Indië 1931-394).

Peraturan tersebut memberi kekuasaan kepada Gubernur Jenderal untuk melarang terbit penerbitan tertentu yang dinilainya dapat mengganggu ketertiban umum. Dalam pasal 1 dinyatakan bahwa Gubernur Jenderal berhak menunjuk penerbitan tertentu yang dilarang terbit untuk sementara, karena tulisan-tulisannya bersifat mengganggu ketertiban umum. Jika tulisan-tulisannya dianggap melunak, pelarangan terbit dapat dicabut. Jika pencabutan pelarangan terbit tidak dilakukan, hal itu berarti bahwa pelarangan terbit berlaku selama satu tahun. Dalam pasal 2 ordonansi ini ditegaskan bahwa Gubernur Jenderal berhak untuk melarang pencetakan, penerbitan dan penyebaran surat kabar paling lama 8 hari. Jika sesudah terbit kembali, surat kabar yang bersangkutan masih dinilai mengganggu ketertiban umum lagi, larangan terbit menjadi lebih lama, namun tidak lebih dari 30 hari berturut-turut.

Selain pasal-pasal yang telah dijelaskan di atas, dalam Indische Staatsregeling (Peraturan Negara Hindia Belanda) ada pasal yang memberi hak exorbitante rechten (hak luar biasa) kepada gubernur jenderal. Berdasarkan pasal 35-37 Indische Staatsregeling, gubernur jenderal mempunyai hak sebagai berikut:

1) Melarang seseorang bertempat di salah satu bagian Hindia Belanda.

2) Mengasingkan seseorang di salah satu tempat dalam wilayah Hindia Belanda.

3) Mengasingkan seseorang dari wilayah Hindia Belanda.

Soewardi Soerjaningrat, Tjipto Mangoenkoesoemo, Douwes Dekker, Marco Kartodikromo, Semaoen, dan H. Misbach adalah beberapa tokoh pergerakan nasional Indonesia yang menjadi korban exorbitante rechten.

\section{b. Peraturan Pemerintah Militer Jepang}

Untuk menguasai Jawa, Jepang berpegang pada dua prinsip yaitu: bagaimana menguasai pikiran rakyat (minshin ha'aku) dan bagaimana menyampaikan propaganda dan menjinakkan mereka (senbu kosaku) 
Prinsip-prinsip ini harus dilaksanakan untuk memobilisasi seluruh rakyat guna mendukung kepentingan Jepang dalam perang Asia Timur Raya, serta untuk merubah mentalitas rakyat secara keseluruhan (Kurasawa, dalam Indonesia, No. 44, October 1987).

Pers dinilai sebagai medium yang sangat strategis untuk menanamkan prinsip-prinsip Jepang tersebut. Oleh karena itu, pemerintah militer Jepang segera memberlakukan kontrol yang sangat ketat terhadap perkembangan dan "suara" pers di Jawa.

Sistem kontrol dilembagakan pertama kali pada tanggal 25 Mei 1942 dalam "undang-undang No. 16 tentang badan-badan pengumuman dan penerangan dan penilikan pengumuman dan penerangan" (Aiko, “Propaganda Media On Java Under Japanese 1942-1945”, dalam Indonesia, No. 44, October 1987.).

Undang-undang ini terdiri atas 12 pasal, yang intinya memberlakukan sistem ijin terbit dan pengawasan preventif. Pasal 1 menyatakan bahwa semua penerbitan harus memiliki ijin terbit, sedangkan pasal 2 melarang setiap penerbitan yang dulu bermusuhan untuk meneruskan pekerjaannya. Walaupun tidak dinyatakan secara eksplisit, yang dimaksud oleh pasal 2 ini termasuk surat kabar Belanda, surat kabar Indonesia yang anti Jepang, dan juga surat kabar Cina yang menentang penyerbuan Jepang terhadap Cina. Pasal 3 menegaskan bahwa penerbitan barang cetak yang bersifat harian, mingguan, bulanan dan yang tidak tentu jangka waktu terbitnya dilarang, kecuali sudah mendapat ijin. Pengawasan preventif dapat dilihat dalam pasal 4 yang menegaskan bahwa sebelum barang cetak diedarkan harus diperiksa dulu oleh bagian sensor balatentara Jepang. Menurut pasal 5 penyebarluasan informasi yang bertentangan dengan kepentingan balatentara Jepang dan pemerintah balatentara Jepang dilarang. Selanjutnya pasal 6 menyatakan bahwa informasi tentang gerakan, pertahanan dan akibat perang tidak boleh disiarkan oleh siapapun, kecuali dengan perantaraan balatentara. Pasal 7 mengharuskan setiap penerbit menuliskan secara tercetak nama pencetak dan penerbit barang cetakannya termasuk surat kabar, buku, surat siaran, surat keterangan. Pasal 8 membatasi daerah penyebaran informasi dengan ketentuan bahwa untuk sementara waktu dilarang untuk mengeluarkan atau memasukkan penerbitan ke atau dari daerah luar. Penerbitan yang dicetak di Indonesia boleh dikirimkan antara Jawa dan Madura dan tempat lain di Indonesia, apabila mendapat ijin balatentara Jepang. Pasal 9 menentukan bahwa perusahaan percetakan yang mencetak untuk orang partikulir harus mendapat izin dari badan sensor balatentara, dan harus menyebutkan nama orang yang menyuruh menyetak, macam barang cetak, serta isinya. Dalam pasal 10 ditentukan kantorkantor sensor terletak di Batavia, Bandung, Semarang, Yogja (atau di Solo), Surabaya, dan kantor sensor tertinggi bertempat di Batavia. Pasal 11 mengatur hukuman bagi para pelanggar undang-undang ini. Bagi pelanggar pasal 4, 7, 8 dan 9 akan dikenakan hukuman penjara paling lama setahun, atau didenda sebanyak-banyaknya seribu rupiah (jumlah ini cukup tinggi, karena nilai tukar rupiah terhadap gulden pada saat itu $1:$ 1). Perkara ini diadili oleh Gunsei Hooin (pengadilan pemerintah balatentara Jepang. 
Pelanggar pasal 2, 3, 5 dan 6 diadili oleh Gunritsu Kaigi (Krijgsraad = pengadilan balatentara). Pasal 12 menetapkan undang-undang ini berlaku sejak diumumkan.

Selanjutnya dalam bagian penjelasan mengenai undang-undang No. 16 diserukan: "sekalian orang jang hidoep dilingkoengan kemakmoeran Asia Raja, djanganlah menganggap atoeran ini sebagai tindakan oentoek menindis pers atau pengoemoeman. Pemerintah hendak melindoengi pers lebih dahoeloe, soepaja ia djangan memboeat kesalahan" (KAN PO, No. Istimewa, bulan 3, 1943).

Pada tahun 1944 pemerintah militer Jepang memandang perlu untuk segera memberlakukan lagi suatu alat kontrol terhadap seluruh media komunikasi massa termasuk pers, film, seni pertunjukan, gambar-gambar, lukisan-lukisan, pidato dan naskah sandiwara yang akan diedarkan serta dipertunjukkan kepada masyarakat. Jepang sangat khawatir jika musuh dapat memanfaatkan media komunikasi yang ada.

Dalam kenyataan, memang Sekutu juga menyebarkan propaganda secara gencar yang dilakukan dengan penyebaran pamflet-pamflet melalui udara. Suatu pamflet berjudul "Soekakah Anak Pembatja Mendjadi Begini?" sangat menarik untuk diperhatikan. Selebaran tersebut mengekspos kondisi heiho di medan perang sebagai berikut:

"Si Djepang pada tanggal 17 October 1944 menyiarkan chabar bahwa toedjoeh heiho mati dimedan perang Burma. Barangkali orang Indonesia belum tahoe bahwa bapaknja, saudaranja, kawannja, oleh si Djepang dikerdjakan seperti boedak boekan sadja di Papoea, di Rabaul, di Truek dan lain-lain tempat, tetapi djoega dihoetan-hoetan Burma! Insjaflah saudara!

(Koleksi RIOD Doos 35, 2.11).

Keterangan tersebut di atas disertai dengan foto orang-orang Indonesia yang menjadi heiho dengan tubuh sangat kurus-kering, tinggal kulit pembalut tulang.

Dalam rangka membendung arus propaganda musuh Jepang itu, pemerintah militer Jepang mengganti undang-undang No. 16 tahun 1942 dengan Osamu Seirei No. 6 tahun 1944 yang mulai berlaku sejak 3 Februari 1944 (Tjahaja, 3 Februari 1944) Osamu Seirei No. 6 tahun 1944 mencakup 16 pasal sebagai berikut.

Pasal 1 ayat 1 menyatakan bahwa surat, gambar, lukisan, yang dapat menghambat usaha perang tentara Jepang, atau mengganggu ketenteraman dan ketertiban umum serta mengganggu pemerintahan militer, tidak boleh diumumkan. Pasal 1 ayat 2 memuat ketentuan bahwa surat, gambar, lukisan, yang dapat merusak kesopanan, tidak boleh diumumkan.

Pasal 2 ayat 1 menegaskan bahwa penerbitan adalah surat, gambar, dan lukisan yang diperbanyak dengan cara dicetak, turunan, dan lain-lain dengan maksud untuk dijual atau disiarkan. Pasal 2 ayat 2 memberi batasan pengertian surat kabar sebagai terbitan yang memiliki nama tetap, diterbitkan pada waktu tertentu atau tidak tertentu dalam 6 bulan, termasuk terbitan istimewa yang memakai nama tetap yang diterbitkan pada waktu lain daripada yang ditetapkan. 
Pasal 3 ayat 1 memuat peraturan bahwa penerbit harus menyerahkan penerbitannya lebih dulu kepada kantor pusat Gunken-etu (sensor balatentara) atau cabangnya untuk diperiksa, serta menyampaikan permohonan ijin kepada Gunseikan. Pasal 3 ayat 2 berisi ketentuan bahwa penerbit atau pencetak advertensi, reklame dan surat sebaran, surat, gambar, lukisan harus memberitahukan bentuk dan isi penerbitannya beserta dengan nama penerbitnya lebih dulu kepada Keisatusyotyoo yang bersangkutan, dan harus mendapat izin untuk memperbanyak penerbitan itu.

Pasal 4 menentukan bahwa barang siapa akan menerbitkan surat kabar, harus minta ijin kepada Gunseikan.

Pasal 5 menyatakan bahwa segala sesuatu yang belum diperiksa oleh kantor pusat Gunken-etu atau cabangnya tidak boleh dimuat dalam surat kabar.

Pasal 6 ayat 1 memuat ketentuan bahwa pada halaman akhir penerbitan harus disebutkan nomor ijin, tanggal ijin, tanggal terbit, nama serta alamat penerbit, pencetak, dan penulis atau penyusun, yang telah mendapat ijin sesuai dengan pasal 3. Pasal 6 ayat 2 memuat ketentuan bahwa pada halaman pertama surat kabar harus disebutkan nomor ijin, tanggal ijin, tanggal terbit, nama serta alamat penerbit, penyusun dan pencetak, yang telah mendapat ijin sesuai dengan pasal 4.

Pasal 7 memuat peraturan bahwa sebelum menyiarkan terbitan atau surat kabar, penerbit harus menyerahkan dua eksemplar kepada Gunseikanbu dan kantor pusat Gunken-etu. Pasal 7 ayat 2 memuat ketentuan bahwa orang yang memperbanyak surat, gambar, lukisan seperti yang ditetapkan dalam pasal 3 ayat 2 harus memberikan dua buah eksemplar kepada Keisatusyotyoo yang bersangkutan.

Pasal 8 berisi ketentuan bahwa barang siapa akan membuat film, harus menyerahkan naskahnya lebih dulu kepada kantor pusat Gunken-etu atau cabangnya untuk diperiksa. Selanjutnya ia harus mengajukan permohonan izin dari Gunseikan, demikian juga jika ia akan membuat turunan film.

Pasal 9 memuat peraturan bahwa film yang belum diperiksa oleh kantor pusat Gunken-etu tidak boleh dipertunjukkan kepada umum.

Pasal 10 ayat 1 memuat ketentuan bahwa penerbitan, surat kabar, dan film yang belum diperiksa isinya oleh kantor pusat Gunken-etu tidak boleh dieksport ke luar Jawa. Pasal 10 ayat 2 berisi ketentuan bahwa terbitan atau surat kabar yang diimport dari luar Jawa tidak boleh dijual atau disiarkan sebelum diperiksa isinya oleh kantor pusat Gunken-etu.

Pasal 11 ayat 1 berisi peraturan bahwa penanggungjawab pertunjukan sandiwara, kesenian dan lainlain harus menyerahkan naskah ceriteranya, acaranya, peralatannya yang sesungguhnya kepada kantor pusat Gunken-etu untuk diperiksa. Pasal 11 ayat 2 menentukan bahwa pertunjukan sandiwara, kesenian yang tidak diizinkan, tidak boleh diselenggarakan.

Pasal 12 ayat 1 berisi ketentuan bahwa barang siapa akan mengadakan pidato, uraian dsb. Di depan rapat umum atau di muka orang berkumpul harus menyerahkan naskah pidatonya itu kepada kantor pusat 
Gunken-etu atau cabangnya untuk diperiksa. Selanjutnya ia harus pula memberitahukan penyelenggaraan itu kepada Kenpetai dan Keisatusyo yang paling dekat.

Pasal 13 ayat 1 menyatakan bahwa Gunseikan boleh melarang penjualan atau penyiaran penerbitan, apabila penerbit atau pencetaknya melanggar undang-undang ini. Pasal 13 ayat 2 menentukan bahwa Gunseikan boleh melarang atau menghentikan penerbitan surat kabr, apabila penerbit, penyusun atau pencetaknya melanggar undang-undang ini. Pasal 13 ayat 3 memuat ketentuan bahwa jika terjadi pelanggaran terhadap kedua ayat di atas, Gunseikan boleh memberi perintah untuk membeslah atau merampas penerbitan atau surat kabar itu.

Pasal 14 ayat 1 memuat ketentuan bahwa barang siapa mengumumkan surat kabar, gambar, lukisan, berlawanan dengan pasa 1 ayat 1 dihukum mati, atau dihukum penjara seumur hidup atau berbatas, atau dihukum denda paling banyak f. 50.000,- Pasal 14 ayat 2 berisi ketentuan bahwa barang siapa mengumumkan surat, gambar, lukisan, berlawanan dengan pasal 1 ayat 2 dihukum penjara paling lama 3 tahun atau dihukum denda paling banyak f. 5.000,-

Pasal 15 memuat ketentuan bahwa barang siapa menerbitkan penerbitan atau surat kabar, membuat film, dan memperbanyaknya, dengan melanggar pasal 3 ayat 1, pasal 4 dan pasal 8, dihukum penjara paling lama 2 tahun atau dihukum denda paling banyak f. 2.000,- $\quad$ Pasal 16 berisi peraturan bahwa barang siapa termasuk dalam salah satu nomor yang tersebut di sini, dihukum penjara paling lama 1 tahun atau dihukum denda paling banyak f. 1.000,-

1. Penerbit atau pencetak advertensi, reklame, dan susrat sebaran, dan juga surat, gambar, lukisan yang melanggar pasal 3 ayat 2 .

2. Penerbit dan penyusun yang melanggar pasal 5 .

3. Penerbit dan penyusun yang melanggar pasal 6.

4. Penerbit atau orang yang memperbanyaak penerbitan atau surat kabar yang melanggar pasal 7.

5. Orang yang mempertunjukkan film, yang melanggar pasal 9 ayat 1 dan 2 .

6. Orang yang mengeksport penerbitan, surat kabar, dan film, yang belum diperiksa, yang berlawanan dengan pasal 10 ayat 1; orang yang yang menjual atau menyiarkan penerbitan atau surat kabar yang berlawanan dengan pasal 10 ayat 2 .

7. Orang yang mempertunjukkan sandiwara, kesenian, kepandaian dsb., yang tidak diperiksa, berlawanan dengan pasal 11 ayat 1, atau mengadakan pertunjukan dengan tidak mendapat ijin, berlawanan dengan pasal 11 ayat 2 .

8. Orang yang mengadakan pidato, uraian dsb., yang berlawanan dengan pasal 1. 


\section{c. Peraturan Pemerintah RI sampai Tahun 1950-1960}

Setelah Indonesia merdeka, peraturan-peraturan tentang pers produk pemerintah kolonial Belanda masih tetap diberlakukan oleh pemerintah Republik Indonesia. Ketentuan-ketentuan dalam perbreidel ordonnantie masih terus diberlakukan dan baru diganti pada tahun 1954. Untuk mengatasi situasi politik, pada tahun 1956, Kepala Staf Angkatan Darat, mengeluarkan peraturan No. PKM/001/0/1956. Pasa 1 peraturan ini menyatakan larangan untuk mencetak, menerbitkan dan menyebarkan serta memiliki tulisan, gambar, klise atau lukisan yang memuat atau mengandung kecaman atau penghinaan terhadap presiden dan wakil presiden. Larangan ini juga berlaku untuk tulisan dan gambar yang dinilai mengandung pernyataan permusuhan, kebencian atau penghinaan (Lucas Luwarso, dalam Daily Press Online http://www.indo-news.com/).

Peraturan pemerintah RI ini mengingatkan kita pada haatzaai artikelen (pasal-pasal tentang menyebaran benih kebencian) yang diberlakukan pada era kolonial Belanda. Akhirnya, Peraturan No. PKM/001/0/1956 ini dicabut setelah diprotes oleh kalangan pers. Sejalan dengan situasi darurat perang (SOB), penguasa militer daerah Jakarta Raya mengeluarkan ketentuan izin terbit (Surat Izin Terbit/SIT) pada tanggal 1 Oktober 1958. Setelah pemberlakuan SOB pada 14 Maret 1957, sering terjadi pembredelan pers dan penahanan sejumlah wartawan. Kemudian peraturan tentang izin terbit dipertegas dengan Penpres No. 6/1963. Setelah peristiwa gerakan 30 Sptember 1965, diberlakukan juga peraturan tentang Surat Izin Cetak (SIC) dan Surat Izin pembagian kertas (SIPK). Jadi perkembangan pers di Indonesia pada saat itu dikungkung oleh peraturanperaturan STI, SIC, dan SIPK.

Dengan mempelajari perkembangan sistem kontrol terhadap pers, dari masa kolonial Belanda, masa penjajahan Jepang, masa setelah kemerdekaan Indonesia sampai dengan tahun 1960-an, diperoleh pemahaman bahwa arus komunikasi massa di Indonesia pada saat itu sangat terhambat oleh berbagai kontrol pemerintah yang bersifat suppresive. Pemahaman semacam ini tentu diperlukan oleh rakyat Indonesia pada umumnya, dan Jawa pada khususnya, untuk mengurangi atau menghilangkan pengikat kebebasan berpikir kritis dan berpendapat melalui pers dalam era demokrasi ini.

\section{B. Pers: Media Ekspresi Nasionalisme Indonesia}

\section{a. Masa Kolonial Belanda}

Perkembangan pendidikan Barat pada akhir abad ke-19, yang kemudian disusul dengan Politik Etis yang dicanangkan pada tahun 1901 dengan salah satu programnya perluasan pendidikan bagi rakyat bumiputera, telah melahirkan sekelompok kecil intelektual bumiputera Indonesia. Dari golongan intelektual ini, muncul kesadaran bahwa untuk mencapai kemajuan, rakyat bumiputera harus mampu bersaing dengan bangsa-bangsa lain. Golongan intelektual bumiputera itu disebut "priyayi baru", yang pada umumnya bekerja sebagai guru atau jurnalis di kota-kota (Sutherland,1979:56-57.) Perluasan pendidikan untuk rakyat bumiputera juga melahirkan masyarakat yang sadar dan mampu membaca. Pers menjadi media yang efektif untuk 
berkomunikasi serta menyebarluaskan ide-ide atau pikiran-pikiran mereka demi kemajuan dan pembebasan bangsa dari segala bentuk penindasan kolonialisme dan imperialisme Belanda.

Pada pertengahan dekade ke-2 abad XX, melalui pers bumiputera menyebar wacana tentang kemajuan yaitu suatu peningkatan status sosial rakyat bumiputera atau peningkatan kehidupan rakyat bumiputera dalam bidang ekonomi, sosial, budaya dan politik. Kemajuan juga dimaknai kemajuan pendidikan, pencerahan, peradaban, modernisasi, dan kesuksesan hidup. Seseorang dianggap telah mencapai kemajuan, jika ia tidak lagi dinilai inferior oleh bangsa lain (Bintang Hindia, No. 4, 1904) Berkaitan dengan wacana kemajuan itu, pers menjadi media untuk diskusi publik tentang gerakan emansipasi, kemajuan, dan pergerakan nasional dalam berbagai warna atau alirannya.

Harian Sinar Djawa memuat artikel tentang perlunya wong cilik untuk menuntut ilmu setinggi mungkin. Dalam surat kabar tersebut dikemukakan dua konsep bangsawan, yaitu "bangsawan usul" dan "bangsawan pikiran". Bangsawan usul mengacu kepada keturunan raja-raja dengan gelar bendara, raden mas, raden ajeng, raden ngabehi, raden ayu, dan lain-lain. Bangsawan pikiran adalah kelompok elite yang telah mendapat pendidikan Barat dengan titel meester, dokter, dan sebagainya. Bangsawan usul, jika tidak disertai pendidikan yang tinggi, bisa hanya bekerja sebagai penjual cao (semacam cendol). Sebaliknya, si Kromo (wong cilik), jika menuntut ilmu sampai menjadi pandai, dapat mencapai tingkat kebangsawanan, yaitu bangsawan pikiran (Sinar Djawa, 15 Februari 1915).

Semangat nasionalisme dapat disimak juga antara lain melalui pernyataan Abdoel Moeis yang disebarluaskan melalui pers sebagai berikut.

Kalau kita mengingat akan nasib boeroeknja tanah air dan bangsa kita, jang beratoes tahoen selaloe ada dalam kungkungan orang lain sadja, maka berdebarlah dada, timboellah soeatoe perasaan jang menggojang segala oerat saraf kita, perasaan kasihan kepada bangsa dan tanah air itoe (Sinar Djawa, 25 Oktober 1917).

Bangsa bumiputera Indonesia ingin juga terbebas dari tekanan kapitalisme yang menggejala sejak akhir abad ke-19, terutama sejak pemberlakuan Undang-undang Agraria tahun 1870. Undang-undang ini memberikan kesempatan kepada kapitalis-kapitalis swasta nonpribumi untuk membeli atau menyewa tanah domain pemerintah kolonial guna membangun perusahaan (Kartodirdjo, Sartono\& Djoko Suryo, 1991:80.). Dengan perluasan modal swasta asing itu, perekonomian rakyat bumiputera semakin terdesak. Semaoen (1899-1971), redaktur harian Sinar Hindia, menampilkan pembahasan tentang terdesaknya perekonomian rakyat bumiputera sebagai berikut.

Kelebihan modal dan kelebihan mesin-mesin dapat oentoek mendirikan fabriek baroe di tanah djadjahan,seperti fabriek goela dan lain-lain di Hindia sini. Dengan adanja fabriek-fabriek ini, maka kapitaal Europa bisa kerdja di tanah djadjahan. Kemadjoean perdagangan Europa ini bisa menindas peroesahaan-peroesahaan Boemipoetera di Hindia, mitsal tenoenan, batikan d.s.b. sama moendoer sebab tidak bisa melawan fabriek-fabriek Europa. Adanja fabriek-fabriek goela, kebon-kebon thee, kofie, tembako d.s.b. mendesak djoega pengelolaan tanah jang semoela dipimpin dan dipiara oleh Boemipoetera. Dengan matinja peroesahaan dan perdagangan ketjil dari Boemipoetera ini maka pentjaharian penghidoepannja soesah sekali dan terpaksalah beriboe-riboe orang Boemipoetera takloek kepada kaoem oeang Europa dan sama djadi kaoem boeroehnja (Sinar Hindia, 7 September 1918). 
Semaoen adalah salah seorang jurnalis bumiputera yang sangat gigih dalam memperjuangkan kebebasan pers. Melalui harian Sinar Hindia, 26 agustus 1918, Semaoen mengutarakan kritik terhadap pemberlakuan Haatzaai Artikelen (pasal-pasal tentang penyebaran benih kebencian) yang menurutnya merupakan alat untuk membelenggu pergerakan rakyat dan untuk melindungi kekuasaan kolonialis serta kapitalis asing.

Djadi terang sekali rakjat dipaksa diam sadja meskipoen pikoelannja berat. Larangan seroepa ini menindas pemboekaan hati dan fikirannja rakjat, hingga rakjat dibikin tetap bodo sebagai sapinja kaoem oeang oleh pemerintah. Apakah dengan kelakoean ini tidak terang bahwa pemerintah mendjadi perkakas jang terbaik boeat kaoem oeang ? Pemerintah djadi perkakasnja kaoem kapitaal dan mengikat dengan tali besi gerakannja rakjat, sedang pemerintah mendjalankan opendeur politiek, artinja memboeka tanah Hindia boeat oeangnja segala bangsa jang diperoesahakan di Hindia.

Dengan politik opendeur maka Hindia akan kemasoekan kapitaal asing begitoe banjak, hingga penghidoepannja anak boemi akan lebih terdesak. Desakan ini hanja bisa dikoerangi kalau rakjat dibikin merdika bergerak dan hendaklah pemerintah memperkenankan rakjat memberi dorongan keras kepada pemerintah dan kaoem oeang dari bangsa apa sadja, dimana perloe. Rakjat bisa beri dorongan, kalau rakjat boleh bergerak serta koeat. Bisa koeat, kalau rakjat boleh keloearkan hati panas jang dibikin sendiri oleh pemerintah.

Toean-toean pembatja awas !

Sebentar lagi ada anak boemi dengan sengadja mentjari pers delict, artinja dengan sengaja melanggar ketentoean-ketentoean dalam strafwetboek, sebab hanja dengan korban jang amat banjak, rakjat akan bangoen betoel (Sinar Hindia, 7 September 1918).

Perkiraan Semaoen itu tidak meleset. Pada tanggal 12 Maret 1919 di Pengadilan Negeri Semarang terjadi persidangan yang mengadili Semaoen karena tulisannya dalam Sinar Hindia, 16 Nopember 1918, yang berjudul "Bala Tentara dan Pertoendjoekan Koeasa"( Sinar Hindia, 15 Maret 1919). Persidangan memutuskan bahwa tulisan tersebut menghina pemerintah (pelanggaran terhadap pasal 154 Strafwetboek), dan karena itu Semaoen dikenai hukuman penjara selama 4 bulan. Semaoen mulai menjalani masa hukumannya di Yogyakarta sejak 24 Juli 1919, dan sebelum berangkat, ia menulis pesan melalui Sinar Hindia sebagai berikut.

Memang banjak alangan dalam pergerakan ! Banjak soesah, banjak korban, banjak pendjara dan bedil. Memang banjak siksaan dan hinaan, tetapi berani tetap bergerak keras jalah perboeatan nomer satoe goena memperbaiki kehidoepan dan akal rakjat, sebagian besar dari manoesia, terangnja memerdekakan rakjat dalam semoea hal. Dan kalau saudara-saudara berboeat begini, maka tentoe akhirnja kita semoea dapat kemenangan (Sinar Hindia, 24 Juli 1919).

Ranjau Haatzaai Artikelen tidak membuat para jurnalis bumiputera jera. Jurnalis yang sangat terkenal "keluar-masuk" penjara karena tuduhan pers delict (pelanggaran terhadap peraturan pers) adalah Marco Kartodikromo (1890-1932). Tulisannya yang sangat terkenal yang membuatnya dihukum penjara selama satu tahun di Batavia adalah kritik terhadap rencana pemerintah kolonial untuk melaksanakan milisi rakyat bumiputera demi Pertahanan Hindia (Indië Weerbaar). Pelaksanaan kampanye Indië Weerbaar bersumber dari ketakutan orang-orang Belanda terhadap perluasan kekuasaan Jepang dan Inggris ke kepulauan Indonesia pada masa Perang Dunia I. Kampanye ini sangat berpengaruh terhadap orang-orang Indonesia yang 
telah sadar politik. Sebagian dari mereka memanfaatkan kampanye itu sebagai sarana untuk menuntut pemerintah kolonial Belanda agar memberi hak politik kepada rakyat melalui perwakilan dalam Volksraad (Dewan Rakyat). Akan tetapi di sisi lain, terutama orang-orang Indonesia yang beraliran marxisme, mengecam Indië Weerbaar sebagai alat untuk melindungi kapitalis asing di negeri ini, dan lembaga itu hanyalah berfungsi sebagai dewan penasehat pemerintah, bukan sebagai lembaga yang memperjuangkan aspirasi dan kepentingan rakyat bumiputera. Marco Kartodikromo menyampaikan kritik tajam terhadap program Indië Weerbaar dalam bentuk syair sebagai berikut.

Indië Weerbaar jang dibitjarakan

Sana sini sama mengatakan

Indië Weerbaar akan memasoekkan

Anak Hindia di lobang meriam.

Oentoeng sekali Anak Hindia

Soedah sama memboeka matanja

Tidak soeka dibikin sendjata

Orang jang menghisap darah kita.

Pers Hindia sama bertereak

Indië Weerbaar itoe tidak lajak

Oentoek kita jang dipandang katak

Oleh bangsa jang terlaloe galak.

Pemerintah kita main soelap

Anak Hindia dibikin kalap

Barang kita sama dianggelap

Oleh orang bertabeat smeerlap (jahat).

Anak Hindia kamoe jang awas

Kepada orang-orang jang boeas

Sebab dia toekang ngerampas

Tanah kita jang terlaloe loeas.

Anak Hindia kamoe pertjaja

Kepada Toehan Maha Koeasa

Si Kianat jang menganiaja

Kepada kamoe Anak Hindia.

Poekoellah dia setengah mati

Kalau perloe boleh sampe mati

Berani itoe senjata kami

Goena hidoep dan mati sedjati (Pantjaran Warta, 14 Februari 1917; dimuat juga dalam Sinar Hindia, 2 September 1918).

Karena tulisannya itu, Marco dikenai tuntutan delik pers dan harus menjalani hukuman penjara selama 1 tahun. Marco adalah seorang jurnalis pemegang prinsip "berani karena benar". Meskipun telah masuk penjara beberapa kali, semangat Marco untuk melontarkan kritik terhadap kebijakan-kebijakan negara kolonial yang menghambat perbaikan hidup rakyat tidak pernah surut. Kritik tajam Marco juga dilontarkan 
untuk kondisi keanggotaan Gemeenteraad (Dewan Kota) Semarang yang sebagian besar adalah orang Eropa. Dalam Sinar Hindia, 24 Agustus 1918, Marco melontarkan kritik terhadap Dewan Kota sebagai berikut.

Tiada seorang wakil rakjat

Bisa mendjadi lid gemeenteraad (anggota dewan kota)

Bila raad-raad itoe main soelap

Soepaja kita selaloe gelap

Kita sekarang tak poenja wakil

Di dalam raad jang banjak begedjil

Setan ini selaloe mengoesil

Memerasi kita orang ketjil

Apa khabar raad sematjam itoe

Tidak lain tentoe main tipoe

Soepaja kita bertambah koeroe

Dan disoeroeh mendjadi soldadoe !

Karena aktivitas jurnalistik dan politik demi perbaikan nasib bangsa, Semaoen dan Marco Kartodikromo adalah orang-orang yang selalu diwaspadai oleh pemerintah kolonial, yang selain menjatuhkan tuntutan delik pers, juga memutuskan untuk mengasingkan mereka dengan dasar hukum exorbitante rechten. Semaoen diasingkan ke negeri Belanda, karena keterlibatannya dalam pemogokan buruh kereta api di Semarang pada Mei 1923, dan Marco Kartodikromo dibuang ke Digul karena ia dituduh terlibat dalam pemberontakan Komunis pada tahun 1926. Pada tahun 1932 Marco wafat di Digul karena penyakit malaria.

Pada awal tahun 1930-an, peranan pers bumiputera sebagai media ekspresi nasionalisme Indonesia semakin tampak nyata. Suatu wacana nasionalisme yang sangat menarik untuk disimak telah disebarluaskan dalam majalah Sendjata Ra'jat, yang terbit sebulan 2x di Semarang. Majalah ini diterbitkan oleh badan komisi pers Partai Indonesia Cabang Semarang. Pada penerbitannya yang pertama, tanggal 29 Desember 1929, majalah ini telah mengeluarkan wacana yang menggelorakan semangat nasionalisme rakyat. Berikut ini adalah cuplikannya.

Pendek kata SENDJATA RA'JAT senantiasa membangoen-bangoenkan soemangat nasional jang sedjati, me-insjaf-insjafkan dan menjedarkan bangsa kita, teroetama dikalangan anggauta partai kita, soepaja kelak kemoedian hari Ra'jat bangsa kita mempoenjai prasaan WADJIB oentoek bekerdja dan berdjoang dalam gelombang pergerakan politiek mentjapai Indonesia Merdika jang seloeas-loeasnja. Segala hal ini didasarkan atas perasaan tjinta, jakin dan ketabahan hati dengan tak memikirkan pajah dan lelah atau beban berat jang menimpa pada dirinja. SENDJATA RA'JAT berani bersikap teroes terang membeberkan sesoeatoe hal jang tidak patoet, jang meroegikan, dan membrantas segala hal mengaboehi mata Ra'jat.

(Sendjata Ra'jat, 29 Desember 1929)

Tulisan di atas menunjukkan bahwa betapa insan pers bumiputera mencita-citakan kemerdekaan bangsa dan tanah air melalui pergerakan politik, dengan basis perjuangan Cinta Tanah Air yang tidak kenal lelah dan berani berkorban jiwa serta raga. 


\section{b. Masa Penjajahan Jepang}

Pada masa penjajahan Jepang, pers di Jawa semakin berada dalam kekangan peraturan-peraturan pemerintah militer Jepang yang sangat otiriter. Sistem kontrol terhadap pers dilembagakan pertama kali pada tanggal 25 Mei 1942 dalam "undang-undang No.16 tentang badan-badan pengumuman dan penerangan dan penilikan pengumuman dan penerangan". Undang-undang ini terdiri atas 12 pasal, yang intinya memberlakukan sistem ijin terbit dan pengawasan preventif.

Dalam suasana sistem pemerintahan Jepang yang militeris dan otoriter itu, pers di Jawa Tengah masih tetap berani mengobarkan spirit nasionalisme dengan berselubung mendukung peraturan pemerintah militer Jepang. Sebagai contoh, pada Desember 1942 pemerintah militer Jepang mengeluarkan peraturan tentang pelarangan penggunaan bahasa Belanda (Kan Po, No. 9, Desember 1942, hlm. 13), dan mengeluarkan ketetapan bahwa bahasa Indonesia menjadi alat komunikasi resmi yang dilengkapi dengan maklumat tentang penyempurnaan bahasa Indonesia (Kan Po, No. 9, Desember 1942, hlm. 7).

Ketetapan dan maklumat pemerintah Jepang tersebut telah membuka peluang bagi jurnalis Indonesia untuk mengobarkan spirit kesadaran nasional. Melalui tulisannya, Sayuti Melik, yang ketika itu menjadi wartawan Sinar Baroe, yang terbit di Semarang, menghimbau kepada seluruh bangsa untuk meninggalkan pemakaian bahasa Belanda dalam percakapan sehari-hari, karena bahasa Belanda di Indonesia telah membawa semangat perbudakan, dan harga diri bangsa Indonesia menjadi rendah. Oleh karena itu, bahasa Indonesia harus dikembangkan dengan suatu kesadaran bahwa bahasa Indonesia tidak kalah dengan bahasabahasa lainnya. Pemakaian bahasa Indonesia harus dilakukan, karena dapat meningkatkan derajat bangsa (Sinar Baroe, 8 Agustus 1942).

Pada masa penjajahan Jepang, para jurnalis Indonesia sangat cerdas dalam mengemas pikiran-pikiran mereka untuk menggelorakan kesadaran kebangsaan Indonesia. Secara tersurat, tulisan-tulisan para jurnalis itu menampakkan dukungan bagi program-program pemerintah Jepang. Secara tersirat tulisan-tulisan mereka mengandung spirit nasionalisme Indonesia yang dikemas sedemikian rupa sehingga dapat mempengaruhi rakyat, tetapi tidak menimbulkan curiga dan amarah bagi pihak pemerintah militer Jepang.

\section{c. Masa Revolusi}

Setelah kemerdekaan Indonesia diproklamasikan oleh Soekarno - Hatta pada tanggal 17 Agustus 1945, peranan pers Indonesia dalam mengobarkan "api" nasionalisme semakin nyata. Masyarakat pers Indonesia terpanggil untuk tetap menguatkan nasionalisme Indonesia, sebab meskipun Indonesia sudah berhasil meraih kemerdekaan, ternyata perjuangan masih panjang. Belanda masih ingin kembali menguasai Indonesia, dan hal ini terbukti bahwa Belanda masih bisa menguasai kembali daerah-daerah tertentu, antara lain Semarang. Dengan memperhatikan kenyataan itu, surat kabar mingguan di kota Semarang, Warta Semarang, memuat 
artikel pada halaman pertama dengan judul "Nasionalisme Indonesia". Berikut ini diketengahkan cuplikan artikel itu.

Berpindahnya kekoeasaan Belanda atas Indonesia ke tangan Djepang, memperhebat pergerakan Nasionalisme kita. Setelah boedjoekan manis Djepang terhadap bangsa Indonesia atas dasar "kemakmoeran bersama" kandas, mereka moelai mendjalankan penindasan terhadap pergerakan kita, sehingga melampaui batas peri-kemanoesiaan. Inilah jang menambah berkobarnja api revoloesi Nasional dan revoloesi kerakjatan kita...................................................Menjerahnja Djepang kepada Serikat memberi kesempatan meletoesnja pergerakan Nasionalisme kita jang selama ini tertindas. Sekarang tibalah saatnja seloeroeh rakjat dengan pemoeda sebagai pelopor melemparkan dan membasmi segala jang mungkin menghalangi kemerdekaan Indonesia. Djangan segan-segan rakjat menoempahkan darahnja goena membela Tanah Air (Warta Semarang, 17 Mei 1946).

\section{Simpulan}

Dari pembahasan yang telah dipaparkan di atas, dapat diambil simpulan sebagai berikut. Pertumbuhan Pers Indonesia dari masa kolonial Belanda sampai dengan masa pascakemerdekaan selalu dinaungi oleh peraturan-peraturan negara yang membelenggu kebebasannya. Namun demikian, dalam belenggu peraturanperaturan negara itu, pers Indonesia justru memiliki kekuatan resiliensi, yaitu kemampuan untuk bertahan dan keluar dari belenggu negara tersebut dengan mengemas informasi-informasi yang bisa lolos dari sensor, sambil tetap menyebarluaskan semangat nasionalisme.

Suatu hal yang tidak dapat disangkal adalah bahwa perkembangan ideologi yang mendukung rezim kolonial mempengaruhi jalan perkembangan pers di negeri ini. Ketika ideologi otoritarian masih menjadi sistem pemikiran di Barat, pers di Indonesia pun berada di bawah kontrol sistem otoritarian. Setelah liberalisme meluas, pihak-pihak swasta asing berpeluang untuk membuka usaha di tanah jajahan ini, termasuk dalam bidang penerbitan surat kabar. Liberalisme dengan prinsip menghargai kebebasan berusaha dan berpendapat, oleh bangsa Indonesia ditangkap sebagai peluang yang sangat bagus untuk membuka usaha penerbitan pers, yang dimaksudkan terutama sebagai "terompet" dalam penyebarluasan semangat nasionalisme.

Akan tetapi, di balik sistem liberal tersebut masih juga bercokol sistem otoriarian. Kondisi itu dapat diperhatikan pada kenyataan bahwa ketika pers bumiputera semakin bersikap kritis terhadap issue-issue kolonial, pemerintah segera menciptakan dan menerapkan rambu-rambu hukum, seperti exorbitante rechten dan haatzaai artikelen, undang-undang No. 16 tahun 1942, yang dipergunakan sebagai alat suppresive bagi jurnalis-jurnalis bumiputera. Demikian juga setelah Indonesia merdeka, prinsip-prinsip otoritarian juga masih berlangsung.

Dengan pemberlakuan dan penerapan peraturan-peraturan pengikat kebebasan pers itu, masyarakat pendukung pers nasional justru semakin tertantang. Spirit nasionalisme Indonesia semakin dikobarkan melalui pers dengan semboyan-semboyan yang attractive seperti "semakin kuat aksi mereka, semakin kuat 
pula tenaga kami berkembang"; "berani karena benar"; "dengan korban yang amat banyak, rakyat akan bangun betul"; "menoempahkan darah goena membela Tanah Air .

Meskipun hidup di bawah kendali sistem pengawasan yang ketat, pers Indonesia telah melaksanakan fungsi social responsibility (tanggung jawab sosial), yang tercermin pada peranannya dalam penyediaan media untuk diskusi publik tentang sistem sosial, politik, ekonomi, dan budaya demi perbaikan kehidupan serta kemerdekaan bangsa dan tanah air.

\section{Daftar Pustaka}

Adam, Ahmat, B., The Vernacular Press and the Emergence of Modern Indonesian Consciousness (18551913), disertasi University of London.

Bijblad op Het Staatsblad van Nederlandsch-Indië, Deel XLVIII, No. 7848-7979, Batavia: Landsdrukkerij.

Bromartani No. 1, 25 Januari 1855, dan Bromartani No. 52, 23 Desember 1856.

Crawford, Robert Henry, The Daily Indonesian-Language Press of Djakarta, Analysis of Two Recent Critical Periods, disertasi, Syracuse University, 1967.

Encyclopaedie van Nederlandsch-Indië, cetakan ke-2, 's-Gravenhage: Martinus Nijhoff, 1917.

Engelbrecht, W.A., Wetten en Verordeningen benevens de Voorlopige Grandwet van de Republiek Indonesia, Leien, 1956.

Faber, G.H. Von, A Short History of Journalism in The Dutch East Indies, Surabaja: G. Kolf \& Co.

Hoogerwerf, Evert-Jan, Persgeschiedenis van Indonesië tot 1942, Geannoteerde Bibliografie, Leiden: KITLV Uitgeverij, 1990.

Inlandsche Pers Overzicht (I.P.O.) No. 4/1920.

Kartodirdjo, Sartono, Pengantar Sejarah Indonesia Baru: Sejarah Pergerakan Nasional Dari Kolonialisme sampai Nasionalisme Jakarta: PT Gramedia, 1990.

Kartodirdjo, Sartono \& Djoko Suryo, Sejarah Perkebunan di Indonesia Kajian Sosial Ekonomi, Yogyakarta: Aditya Media, 1991.

Lievegoed, "De Journalistiek in Indië: 50 Jaren Geleden en Thans", dalam De Indische Gids, jg. 51, Amsterdam, 1929.

Kwantes, R.C. , De Ontwikkeling van de Nationalistische Beweging in Nederlandsch-Indië, 1928-1933, bronnenpublikatie, derde stuk, Groningen: Wolters-Noordhoff/Boumas’s Boekhuis, 1981.

Oey Hong Lee, Indonesian Government and Press During Guided Democracy, Hull, England: Center for South-East Asian Studies, The University of Hull, 1971. 
Oemar Senoadji, “Kemerdekaan Pers di Indonesia”, dalam Almanak pers Indonesia 1945-1955, 1955.

Rachmadi, F., Perbandingan Sistem Pers - Analisis Deskriptif Sistem Pers di Berbagai Negara, Jakarta: PT Gramedia, 1990.

Soebagijo I.N., "Peranan Media Massa Dalam Pengembangan Sastra Daerah", dalam Majalah Pers Indonesia, No. 15, Tahun IV, Juli 1978

Soebagijo I.N., Sebelas Perintis Pers Indonesia ,Jakarta: Djambatan, 1976.

Soebagijo I.N., Abdurrachman Soerjomihardjo, P. Swantoro, Lintasan Sejarah P.W.I., Jakarta: P.W.I. Pusat \& Departemen Penerangan, 1977.

Staatsblad 1914 No. 205, Batavia: Landsdrukkerij.

Soebagijo I.N., Sejarah Pers Indonesia, Jakarta: Dewan Pers, 1977.

Soerjomihardjo,Abdurrachman(red.), Beberapa Segi Perkembangan Sejarah Pers di Indonesia, Jakarta: DEPPEN R.I. - LEKNAS LIPI, 1980.

Soeharto, Pitut dan A. Zainoel Ihsan (red.), Belenggu Ganas, Jakarta: Aksara Jayasakti, 1982.

Sutherland, Heather, The Making of A Bureaucratic Elite The Colonial Transformation of The Javanese Priyayi, Singapore, Kuala Lumpur, Hong Kong: Heinemann Educational Books (Asia) Ltd., 1979.

Taufik, I., Sejarah dan Perkembangan Pers di Indonesia Jakarta: P.T. Triyinco, 1977.

Wal, Van der, (ed.) De Opkomst van De Nationalistische Beweging inNederlandsch-Indië, Groningen, 1967.

Wormser, C.W., Journalistik op Java, Uitgeverij W. Van Hoeve, 1941.

\section{Surat Kabar}

Bintang Hindia, No. 4, 1904.

De Express, 19 Juli 1913.

De Express, 5 Agustus 1913.

KAN PO, Nomor Istimewa, bulan 3, 1943.

Kan Po, No. 9, Desember 1942.

Pantjaran Warta, 14 Februari 1917.

Pemberita Betawi, 8 Agustus 1913.

SENDJATA RA'JAT, 29 Desember 1932.

Sinar Djawa, 28 Mei 1914.

Sinar Djawa, 15 Februari 1915.

Sinar Djawa, 3 Agustus 1917.

Sinar Djawa, 3 Agustus 1917.

Sinar Djawa, 25 Oktober 1917.

Sinar Hindia, 26 Agustus 1918.

Sinar Hindia, 2 September 1918.

Sinar Hindia, 7 September 1918.

Sinar Hindia, 15 Maret 1919.

Copyright (C2018, ISSN: 2598-3040 online 
Sinar Hindia, 24 Juli 1919.

Sinar Baroe, 8 Agustus 1942.

Warta Semarang, 17 Mei 1946.

Copyright (@2018, ISSN: 2598-3040 online 